\title{
SISTEM PENUNJANG KEPUTUSAN PENILAIAN KINERJA GURU DENGAN METODE ANALYTICAL HIRARCHY PROCESS (AHP) DAN METODE SIMPLE ADDITIVE WEIGHT (SAW) PADA SDIT AMAL MULIA
}

\author{
Eka Hadi Subekti ${ }^{1)}$, Anita Diana ${ }^{2)}$ \\ Sistem Informasi, Fakultas Teknologi Informasi, Universitas Budi Luhur \\ Jl. Raya Ciledug, Petukangan Utara, Kebayoran Lama, Jakarta Selatan 12260 \\ E-mail : ekahadisubekti396@gmail.com ${ }^{1)}$, anita.diana@budiluhur.ac.id ${ }^{2)}$
}

\begin{abstract}
Abstrak
Penilaian kinerja guru diharapkan meningkatkan semangat, motivasi dan profesionalisme para guru. Masalah yang dihadapi antara lain, proses penilaian masih dilakukan secara manual menggunakan form penilaian dengan didasarkan pada analisa pribadi pihak penilai sekolah SDIT Amal Mulia, sehingga membutuhkan waktu yang lama proses perhitungan hasil penilaian, dan memungkinkan terjadi kesalahan. Selain itu, masing-masing kriteria yang digunakan tidak memiliki bobot, sehingga tidak terlihat keuunggulan masing-masing guru pada kriteria tertentu dalam hasil penilaian. Berdasarkan hal itu, maka dibuatlah suatu sistem pendukung keputusan penilaian kinerja guru yang dapat membantu pihak sekolah dalam menentukan siapa saja guru yang berhak menjadi guru terbaik. Sistem ini dibangun dengan menggunakan Metode Analytical Hierarchy Process (AHP) untuk pembobotan kriteria, dan Metode Simple Additive Weighting(SAW) untuk perangkingan guru terbaiknya. Beberapa kriteria yang telah ditentukan oleh pihak sekolah, yaitu menguasai karakteristik peserta didik, menguasai teori belajar dan prinsip pembelajaran yang mendidik, pengembangan kurikulum, kegiatan pembelajaran yang mendidik, pengembangan potensi peserta didik, dan komunikasi dengan peserta didik.. Penelitian akan menghasilkan sebuah sistem pendukung keputusan untuk mempermudah pengambilan keputusan guru terbaik dengan cepat dan lebih baik, mengetahui kriteria prioritas dan melihat keunggulan masing- masing guru pada kriteria tertentu, serta menghasilkan keputusan lebih objektif berupa daftar rekomendasi perankingan guru terbaik pada SDIT Amal Mulia.
\end{abstract}

Kata kunci: SPK, AHP, SAW, Penilaian guru

\section{PENDAHULUAN}

Penggunaan perangkat teknologi dan pemanfaatan teknologi serta pelayanan menggunakan aplikasi yang sesuai kebutuhan dapat mempermudah setiap proses komputerisasi di era sekarang, sehingga proses dalam pengelolaan data yang akan dilakukan sangat efisien dan menghemat waktu. Salah satu bidang tersebut adalah sistem pendukung keputusan yang dapat membantu dalam pengambilan keputusan. Sistem Pendukung Keputusan(SPK) atau dikenal dengan Decision Support System (DSS), pada tahun 1970-an sebagai pengganti istilah Management Information System (MIS). Tetapi pada dasarnya SPK merupakan pengembangan lebih lanjut dari MIS yang dirancang sedemikian rupa sehingga berifat alternatif dengan pemakainya.

Yang menjadi tempat penelitian adalah SDIT Amal Mulia Kota Depok. Sedangkan yang menjadi fokus penelitian ini adalah penilaian pemilihan guru terbaik. Dimana di SDIT tersebut belum adanya sistem yang mendukung dalam penilaian pemilihan guru terbaik untuk meningkatkan sumber daya dalam hal mengajar siswa untuk mendapatkan ilmu yang bermanfaat selama sekolah di SDIT Amal Mulia. Pada setiap akhir tahun, SDIT Amal Mulia melakukan proses penilaian kinerja masing-masing guru. Hasil penilaian kinerja tersebut menjadi dasar untuk mengetahui performa kerja guru sepanjang tahun. Proses penilaian kinerja guru saat ini masih dilakukan dengan menggunakan form penilaian, sehingga membutuhkan waktu yang lama untuk memproses hasil penilaian. Dan memungkinkan pula untuk terjadinya kesalahan proses penilaian. Kriteria saat ini pun tidak memiliki bobot, sehingga tidak diketahui kriteria prioritas, serta tidak terlihat keunggulan masing-masing guru pada kriteria tertentu dalam hasil penilaian.

Berdasarkan permasalahan tersebut, maka pada penelitian ini diusulkan sistem pendukung keputusan untuk penilaian kinerja guru dengan menggunakan metode Analytical Hirarchy Process (AHP) untuk menentukan bobot kriterianya, dan metode Simple Additive Weighting (SAW) utnuk perangkingan guru terbaiknya. Penggunaan metode Analytical Hirarchy Process (AHP) dikarenakan belum adanya pembobotan disetiap kriteria. Dan penggunaan metode Simple Additive Weighting (SAW) dikarenakan metode SAW dapat melakukan perhitungan yang dapat menghasilkan perangkingan nilai terbesar hingga terendah yang nantinya akan di jadikan ranking alternatif. Sedangkan manfaat yang diperoleh dengan adanya penelitian ini adalah membantu proses penilaian kinerja guru pada SDIT Amal Mulia. Dengan adanya sistem ini diharapkan mempermudah kepala TU untuk memberikan laporan hasil penilaian kinerja kepada pihak kepala sekolah, sehingga dalam menentukan guru terbaik dapat dilakukan secara objektif. 
Penelitian sebelumnya telah dilakukan menggunakan metode AHP dalam menentukan pemilihan desa terbaik menggunakan metode AHP, yang telah dilakukan oleh Tri Rahayu, Erly Krisnanik, dan Bayu Hananto [1], Pada penelitian ini menyatakan bahwa metode AHP ini membantu memecahkan persoalan yang kompleks dengan menstruktur suatu hirarki kriteria, pihak yang berkepentingan, hasil dan dengan menarik berbagai pertimbangan guna mengembangkan bobot atau prioritas. Analytical Hierarchy Process dapat dijadikan sebagai alat bantu dalam menentukan Desa Terbaik. Hasil pembobotan antar kriteria dapat dijadikan sebagai rekomendasi alternatif.

Penilaian kinerja guru dengan metode Analitycal Hierarchy Procces (AHP) dapat mempermudah pegawai dalam bekerja secara baik dan optimal. Penelitan lain dengan metode AHP oleh W. D. Puspitasari bersama D. K. Ilmi [2] menyatakan bahwa sistem pendukung keputusan pemilihan dosen berprestasi ini menggunakan metode Analytical Hierarchy Process (AHP) yang dilakukan dengan membuat nilai matriks berpasangan untuk masingmasing kriteria. Data penilaian dosen akan dihitung dengan nilai matriks berpasangan dan hasil dari perhitungan tersebut akan muncul berbentuk rating nilai. Rating nilai dosen yang tertinggi, berhak untuk menjadi dosen berprestasi di Universitas Islam Balitar.

Penelitan lainnya menggunakan metode SAW oleh R. S. Hutasoit, A. P. Windarto, D. Hartama, S. Solikhun [3] menyatakan bahwa Metode Simple Additive Weighting (SAW) ini dipilih karena dapat menentukan nilai bobot untuk setiap atribut, kemudian dilanjutkan dengan proses perankingan yang akan menyeleksi alternatif terbaik dari sejumlah alternatif yang ada. Dengan metode perangkingan tersebut diharapkan penilaian akan lebih tepat karena didasarkan pada nilai kriteria dan bobot yang sudah ditentukan sehingga akan mendapatkan hasil yang lebih maksimal.

Penelitian lain oleh Fara Atika [4] menyatakan penelitian ini bertujuan untuk membuat suatu Decision Support System (DSS) dengan metode Simple Additive Weighting (SAW) berbasis web untuk mempermudah dalam pemilihan guru berprestasi secara cepat dan akurat tanpa membutuhkan waktu yang lama dalam perhitungannya. Hasil yang ada akan dirangking sesuai dengan perhitungan yang ada pada metode SAW.

Penelitian terdahulu yang menggunakan metode AHP dan SAW dilakukan oleh D. Mahdiana, N. Kusumawardhany [5] Pada penelitian ini bertujuan mengembangkan model sistem pendukung keputusan pemilihan dosen terbaik pada Fakultas Teknologi Informasi Universitas Budi Luhur menggunakan kombinasi metode Analytical Hierarchy Process dan Simple Additive Weighting. Hasil perhitungan uji consistency ratio (CR) untuk kriteria pemilihan dosen terbaik didapat nilai $\mathrm{CR}=0.06$, hasil perhitungan tidak lebih dari 0.1 atau $10 \%$, sehingga penilaian perbandingan kriteria pemilihan dosen terbaik sudah konsisten dan tidak memerlukan revisi penilaian.

Dengan demikian penulis menggunakan kombinasi metode AHP dan SAW dalam penilaian kinerja guru untuk penentuan guru terbaik pada SDIT Amal Mulia.

\section{METODE PENELITIAN}

\subsection{Rumusan Masalah}

Penulis mencoba merumuskan masalah yang berhasil diidentifikasi dalam penilaian kinerja guru ini, yakni proses penilaian masih dilakukan secara manual dengan menggunakan form penilaian, sehingga membutuhkan waktu yang lama untuk melakukan proses perhitungan hasil penilaian, serta mungkin timbul kesalahan dalam proses penilaian dan perhitungannya. Dan juga masing-masing kriteria yang digunakan tidak memiliki bobot, sehingga tidak terlihat keunggulan masing-masing guru pada kriteria tertentu dalam hasil penilaian. Hasil penelitian ini adalah membuat sistem penunjang keputusan untuk penilaian kinerja guru terbaik ditujukan untuk memudahkan pihak SDIT Amal Mulia dalam membuat keputusan yang tepat dan akurat. Setelah mengidentifikasi masalah dan kriteria yang digunakan maka penulis mencari studi literatur yang sesuai dengan judul yang ingin dibuat.

\subsection{Metode Pengumpulan Data}

Tahapan pengumpulan data dilakukan dengan cara observasi, wawancara, dan analisa dokumen langsung ke SDIT Amal Mulia. Tahapan observasi dilakukan dengan cara pengamatan langsung pada SDIT Amal Mulia dengan proses penilaian kinerja guru terbaik menggunakan form penilaian sebagai data masukan penelitian ini. Tahapan wawancara secara langsung kepada Kepala Staff TU yang terlibat secara langsung untuk obyek penelitian, yang berkaitan dengan proses pemilihan/ guru terbaik. Penulis juga mendapatkan dokumen-dokumen yang digunakan pada proses yang sedang berjalan, formulir penilaian kinerja guru. Penulis juga membagikan kuisioner untuk menentukan perbandingan kepentingan antara kriteria yang digunakan dalam penilaian kinerja guru.

\subsection{Analisa Data}

Tahapan analisis data yaitu dengan menganalisis hasil dokumen yang sudah didapat dengan cara observasi, wawancara dan pembagian kuesioner. Penulis menganalisa proses bisnis yang sedang berjalan pada SDIT Amal Mulia. Proses analisa dokumen ini dilakukan agar memperoleh informasi yang sesuai dengan sistem yang akan dibuat. Setelah menganalisis data penulis mendapatkan 6 kriteria yang sudah ditentukan oleh SDIT Amal Mulia yaitu menguasai karakteristik peserta didik, menguasai teori belajar dan prinsip 
pembelajaran yang mendidik, pengembangan kurikulum, kegiatan pembelajaran yang mendidik, pengembangan potensi peserta didik, dan komunikasi dengan peserta didik.

\subsection{Desain Model}

Tahap desain model yaitu menentukan Metode SPK dengan cara memilih metode yang tepat untuk pemilihan guru terbaik. Berdasarkan kriteria-kriteria yang diberikan maka metode AHP digunakan untuk penentuan bobot kriteria yang belum ada, dan metode SAW dipilih untuk penentuan rangking guru terbaik. Diharapkan dengan kombinasi metode AHP dan SAW dapat memberikan hasil yang cepat, akurat dan lebih obyektif sesuai kriteria.

\subsection{Perancangan Sistem}

Tahap perancangan sistem SPK, yaitu dengan merancang model sistem SPK pemilihan guru terbaik dengan menggunakaan fishbone, Unified Modelling Language (UML), perancangan basis data, dan prototype sistem. UML yang digunakan peneliti Activity Diagram,Use Case Diagram, Sequence Diagram,Class Diagram.

Perancangan Basis Data yang digunakan peniliti adalah ERD (Entity Relationship Diagram) dan LRS (Logical Record Structure)

\subsection{Prototype}

Proses pengembangan sistem seringkali menggunakan pendekatan prototipe (prototyping). Metode ini sangat baik digunakan untuk menyelesesaikan masalah kesalahpahaman antara user dan analis yang timbul akibat user tidak mampu mendefinisikan secara jelas kebutuhannya.

Prototyping adalah pengembangan yang cepat dan pengujian terhadap model kerja (prototipe) dari aplikasi baru melalui proses interaksi dan berulangulang yang biasa digunakan ahli sistem informasi dan ahli bisnis. Prototyping disebut juga desain aplikasi cepat (rapid application design/RAD)karena menyederhanakan dan mempercepat desain sistem [6].

\subsection{Definisi Sistem Penunjang Keputusan}

Konsep Sistem Pendukung Keputusan (SPK) atau Decision Support System (DSS) pertama kali diungkapkan pada awal tahun 1970-an oleh Michael S. Scott Morton dengan istilah Management Decision System. Sistem tersebut adalah suatu sistem yang berbasis komputer yang ditujukan untuk membantu pengambil keputusan dalam memanfaatkan data dan model tertentu untuk memecahkan berbagai persoalan yang tidak terstruktur. Sistem Pendukung Keputusan (Decision Support System) adalah sekumpulan produser berbasis model untuk data pemrosesan dan penilaian guna membantu para manajer mengambil keputusan [7].
Menurut Turban [8] komponen Sistem Penunjang Keputusan dapat dibangun dari subsistem berikut ini :

a. Subsistem Manajemen Data

b. Subsistem Manajemen Model

c. Subsistem Antar muka

d. Subsistem Manajemen Pengetahuan

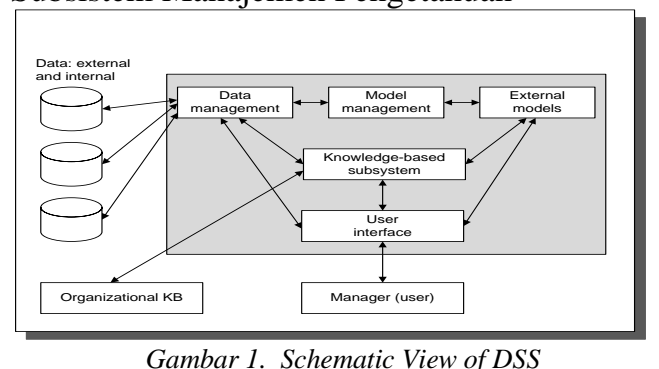

Dalam sebuah Sistem Pendukung Keputusan, proses pengambilan keputusan harus melalui beberapa proses [8]. Proses pengambilan keputusan tersebut meliputi tiga fase utama, Intellegence, Design dan Choice, kemudian menambahkan fase keempat, yaitu Implementation yang diperkenalkan oleh Simon pada tahun 1997. Gambar konseptual dalam proses pengambilan keputusan ditunjukan pada gambar berikut:

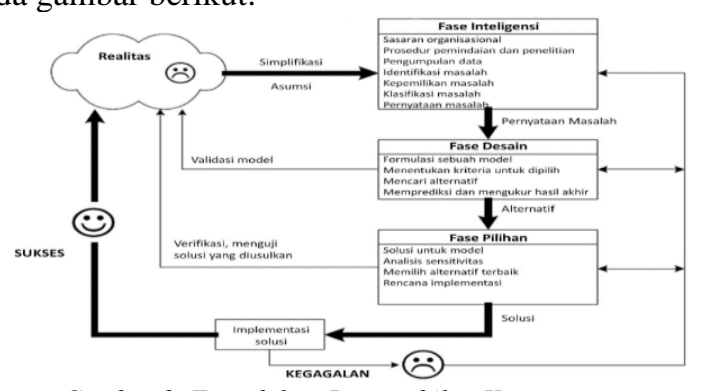

Gambar 2. Fase dalam Pengambilan Keputusan

a. Fase Inteligensi: identifikasi suatu masalah.

b. Fase Desain: meliputi kegiatan mengembangkan dan menganalisa kemungkinan alternatif solusi, termasuk menguji beberapa kemungkinan solusi. Sebuah model dari masalah dalam pengambilan keputusan dibangun, diuji dan divalidasi.

c. Fase Pilihan: merupakan tahapan kritis dalam pengambilan keputusan, dimana memiliki pencarian, evaluasi dan keputusan rekomendasi terhadap suatu solusi yang tepat untuk model.

d. Fase Implementasi: bentuk realisasi dari pemilihan sebuah solusi yang direkomendasikan untuk diaplikasikan.

\subsection{Metode Analytic Hierarchy Process (AHP)}

AHP merupakan suatu model pendukung keputusan yang dikembangkan oleh Thomas L. Saaty. Model pendukung keputusan ini akan menguraikan masalah multi faktor atau multi kriteria yang kompleks menjadi suatu hirarki [9]. Pada umumnya AHP digunakan dengan tujuan untuk menyusun prioritas dari berbagai alternatif pilihan 
yang ada dan pilihan-pilihan tersebut bersifat kompleks atau multikriteria.

AHP adalah pengambilan keputusan multikriteria dengan dukungan metodologi yang telah diakui dan diterima sebagai prioritas yang secara teori dapat memberikan jawaban yang berbeda dalam masalah pengambilan keputusan serta memberikan peringkat pada alternatif solusinya. [10] Metode AHP dikembangkan oleh Thomas L. Saaty, seorang ahli matematika. Metode ini adalah sebuah kerangka untuk mengambil keputusan dengan efektif atas persoalan yang kompleks dengan menyederhanakan dan mempercepat proses pengambilan keputusan dengan memecahkan persoalan tersebut kedalam bagian-bagiannya, dalam suatu susunan hirarki.

Langkah-langkah dalam pemilihan keputusan menggunakan AHP:

1. Mendefinisikan masalah dan menentukan solusi yang diinginkan

2. Menyusun masalah ke dalam. Hierarki yang di awali dengan tujuan yang sama

3. Menyusun prioritas untuk setiap elemen kriteria dan alternatif

4. Membuat matriks berpasangan.

Formulasi Perhitungan Metode AHP:

1. Menormalkan data, Dengan membagi nilai dari setiap elemen didalam matriks yang berpasangan dengan nilai total dari setiap kolom.

2. Menghitung nilai eigen vector dan menguji konsistensinya.

3. Menghitung eigen vector dari setiap perbandingan.

4. Menguji konsistensi hierarki.

Dimana:

$$
C I=\frac{\lambda \text { maksimum }-n}{n-1}
$$

$$
\begin{array}{ll}
\mathrm{CI} & =\text { Indeks Konsistensi } \\
\lambda \text { maksimum }= & \text { nilai eigen terbesar dari matriks } \\
& \text { berordo } \mathrm{n} . \\
\mathrm{n} & =\text { jumlah kriteria }
\end{array}
$$

Nilai eigen terbesar didapat dengan menjumlahkan hasil perkalian jumlah kolomdengan vektor prioritas.

$$
C R=\frac{C I}{R I}
$$

Dimana nilai Random Index (RI) berdasarkan perhitungan Saat yang disajikan pada tabel 1 .

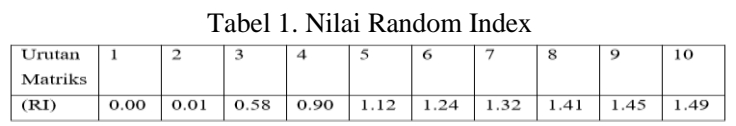

\subsection{Metode Simple Additive Weighting (SAW)}

Metode penjumlahan terbobot sering juga dikenal dengan istilah metode Simple Additive Weighting (SAW) mempunyai konsep mencari perjumlahan bobot dan nilai alternatif yang ada pada atribut [11]. Output yang akan dihasilkan adalah urutan nilai alternatif dari penilaian kinerja guru yang tertinggi hingga alternatif dengan nilai terendah.
Metode SAW membutuhkan proses normalisasi matriks keputusan (X) ke suatu skala yang dapat diperbandingkan dengan semua rating alternatif yang ada. Menurut Fishburn [12] ada beberapa langkah dalam penyelesaian metode SAW :

1) Menentukan kriteria-kriteria yang akan dijadikan acuan dalam pengambilan keputusan, yaitu $\mathrm{Cj}$

2) Menentukan nilai bobot dari masing-masing kriteria.

3) Menentukan rating kecocokan setiap alternatif pada setia kriteria

4) Menentukan Matriks keputusan berdasarkan kriteria $(\mathrm{Cj})$, kemudian melakukan normalisasi matriks berdsarkan persamaan yang diseusaikan dengan jenis atribut sehingga diperoleh matriks ternormalisasi R.

5) Memberikan nilai prefensi untuk setiap alternatif (Vi)

$$
\begin{aligned}
& R_{i j}
\end{aligned}
$$

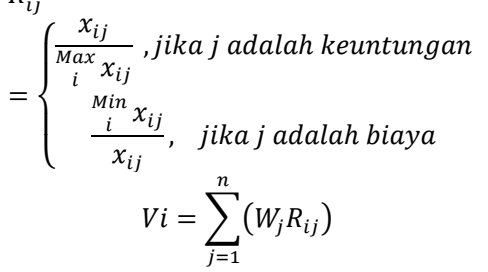

Keterangan :

$$
\begin{aligned}
& \mathrm{Vi}=\text { Rank untuk setiap alternatif } \\
& \mathrm{Wj}=\text { Nilai Bobot dari setiap kriteria } \\
& \mathrm{Rij}=\text { Nilai kinerja ternormalisasi }
\end{aligned}
$$

Hasil akhir diperoleh dari proses perangkingan yaitu penjumlahan dari perkalian matriks ternormalisasi $\mathrm{R}$ dengan vector bobot sehingga diperoleh nilai terbesar yang dipilih sebagi alternatif terbaik (Ai) sebagai solusi.

\section{HASIL DAN PEMBAHASAN}

\subsection{Analisa Masalah}

Dalam menganalisa masalah pada penilaian kinerja guru, penulis menggunakan Fishbone Diagram. Dalam menganalisa masalah tersebut, ada 3 kategori. Kategori manusia belum adanya aplikasi SPK pemilihan guru terbaik. Kategori proses, penilaian tidak objektif. Kategori metode, belum adanya bobot kriteria. Masalah utama yang ada pada ujung kepala ikan, yaitu sulit mengambil keputusan untuk penilaian kinerja guru. Hal ini disajikan pada gambar 1

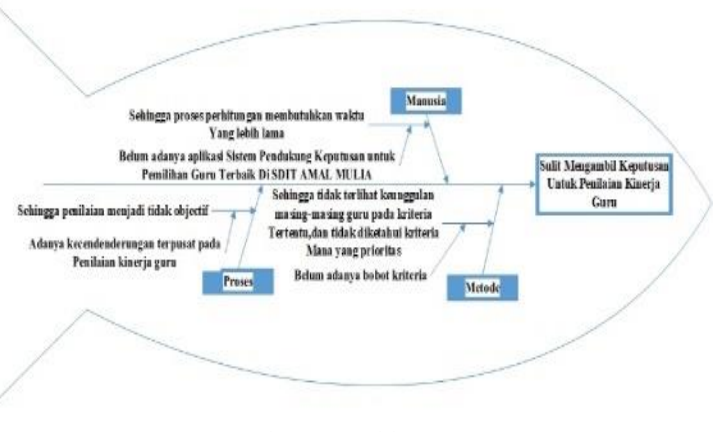

Gambar 3. Fishbone Diagram 


\subsection{Proses Bisnis}

Proses dimulai dari Tata Usaha Menyiapkan Form Penilaian Kinerja Guru Per Semester, Kemudian Tata Usaha Mengsisi Form penilaian, Kemudian Tata Usaha Membuatkan Laporan Penilaian Kinerja Guru, Setelah itu Tata Usaha Menyerahkan Laporan Penilaian Kinerja Guru, Kemudian Kepala Sekolah mengecek Laporan Penilaian Kinerja Guru dan Kepala Sekolah Menerima Laporan. Proses ini dapat dilihat pada gambar 2.

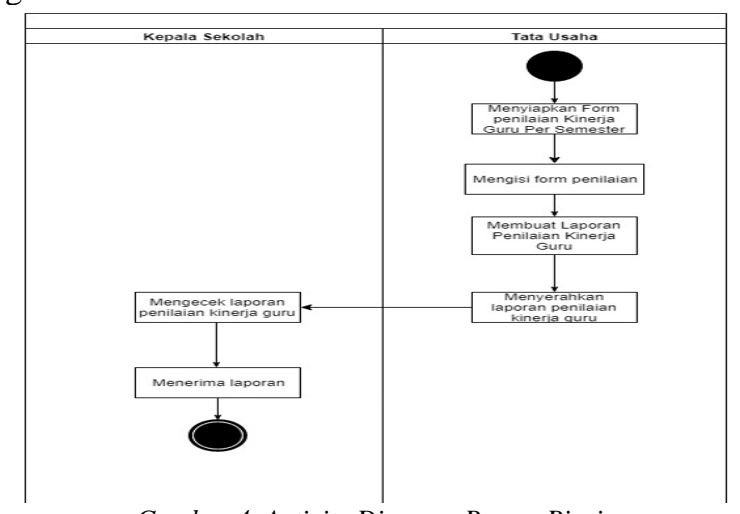

Gambar 4. Activity Diagram Proses Bisnis

\subsection{Perhitungan dengan metode AHP}

Penetapan kriteria diperoleh dari kriteria yang ada SDIT Amal Mulia. Gambar 3 menunjukan struktur hirarki permasalahan yang ingin diteliti yaitu penentuan guru terbaik berdasarkan beberapa kriteria.

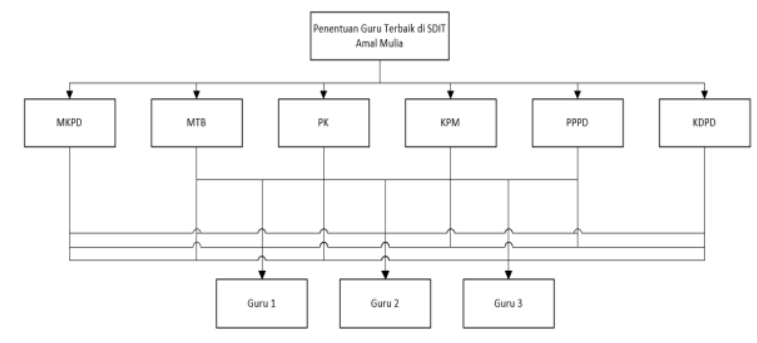

Gambar 5. Struktur Hirarki Penentuan Guru Terbaik

\subsection{Perbandingan Kepentingan Antar Kriteria}

Berdasarkan kuesioner yang telah diajukan kepada responden maka didapat tabel perbandingan antar kriteria yang ada pada tabel 2 .

Tabel 2. Tabel Perbandingan Antar Kriteria

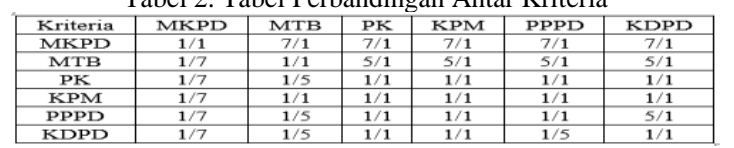

\section{Langkah 1}

Menghitung setiap perbandingan antar kriteria, lalu ubah hasilnya ke angka decimal.

Tabel 3. Tabel Perbandingan Antar Kriteria

\begin{tabular}{|c|c|c|c|c|c|c|}
\hline Kriteria & MKPD & MTB & PK & KPM & PPPD & KDPD \\
\hline MKPD & 1,000 & 7,000 & 7,000 & 7,000 & 7,000 & 7,000 \\
\hline MTB & 0,143 & 1,000 & 5,000 & 5,000 & 5,000 & 5,000 \\
\hline PK & 0,143 & 0,200 & 1,000 & 1,000 & 1,000 & 1,000 \\
\hline KPM & 0,143 & 0,200 & 1,000 & 1,000 & 1,000 & 1,000 \\
\hline PPPD & 0,143 & 0,200 & 1,000 & 1,000 & 1,000 & 5,000 \\
\hline KDPD & 0,143 & 0,200 & 1,000 & 1,000 & 0,200 & 1,000 \\
\hline
\end{tabular}

2. Langkah 2

Jumlahkan setiap kolom.

Contoh: MKPD: $1,000+0,143+0,143+0,143+0,143+$ $0,143=1,745$
Tabel 4. Hasil Penjumlahan Kolom Tabel Perbandingan Antar Kriteria

\begin{tabular}{|c|c|c|c|c|c|c|}
\hline Kriteria & MKPD & MTB & PK & KPM & PPPD & KDPD \\
\hline MKPD & 1,715 & 8,800 & 16,000 & 16,000 & 15,200 & 20,000 \\
\hline
\end{tabular}

\section{Langkah 3}

Normalisasi tabel seperti pada tabel 3, dengan cara membagi setiap angka dengan hasil penjumlahan tiap kolom seperti pada tabel 4.

Contoh: MTB.

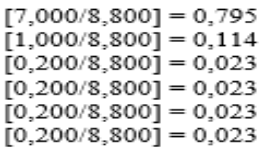

Tabel 5. Hasil Normalisasi Tabel Perbandingan Antar Kriteria

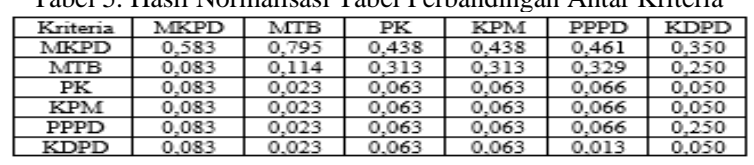

\section{Langkah 4}

Selanjutnya menjumlahkan hasil setiap baris tabel hasil normalisasi. Lalu bagi dengan banyaknya kriteria, penelitian ini menggunakan 6 kriteria. Sehingga, hasilnya akan menjadi nilai bobot setiap kriteria. Lalu jumlahkan seluruhnya, dan hasil nya harus 1.

Contoh: PK

(a) $0,083+0,023+0,063+0,063+0,066+0,050=0,347$

(b) $0,347 / 6=0,058$

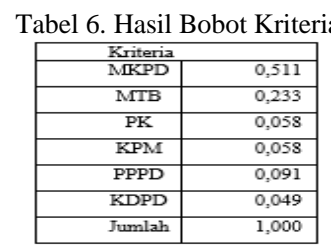

\subsection{Pengujian Metode AHP}

Pengujian metode AHP dilakukan dengan cara menghitung nilai Consistency Index (CI) dan nilai Consistency Ratio (CR). Ada 6 langkah untuk pengujian AHP, yaitu.

1. Langkah 1

Langkah pertama adalah mengalikan angka di pada tabel perbandingan antar kriteria yang ada pada tabel 3 dengan bobot kriteria nya masing masing seperti pada tabel 7.

Bobot Kriteria MKPD $=0,511$

$$
\begin{aligned}
& \text { Perkalian }=\quad[1,000 * 0,511]=0,511 \\
& {[0,143 * 0,511]=0,073 } \\
& {[0,143 * 0,511]=0,073 } \\
& {[0,143 * 0,511]=0,073 } \\
& {[0,143 * 0,511]=0,073 } \\
& {[0,143 * 0,511]=0,073 }
\end{aligned}
$$

Tabel 7. Hasil Perbandingan Tabel Perbandingan Antar Kriteria Dengan Bobot Kriteria

\begin{tabular}{|c|c|c|c|c|c|c|}
\hline Rriteria & MKPD & MTB & PK & KPM & PPPD & KDPD \\
\hline MKPD & 0,511 & 1,634 & 0,405 & 0,405 & 0,638 & 0,343 \\
\hline MTB & 0,073 & 0,233 & 0,289 & 0,289 & 0,456 & 0,245 \\
\hline PK & 0,073 & 0,047 & 0,058 & 0,058 & 0,091 & 0,049 \\
\hline K.PM & 0,073 & 0,047 & 0,058 & 0,058 & 0,091 & 0,049 \\
\hline PPPD & 0,073 & 0,047 & 0,058 & 0,058 & 0,091 & 0,245 \\
\hline KDPD & 0,072 & 0,047 & 0,029 & 0,014 & 0,083 & 0,044 \\
\hline
\end{tabular}

2. Langkah 2

Jumlahkan seluruh baris pada tabel hasil perkalian seperti pada tabel 7. Maka akan menghasilkan Weighted Sum. 
Contoh: PPPD: $0,073+0,047+0,058+0,058+0,091+0,245$ $=0,572$

Tabel 8. Weighted Sum
\begin{tabular}{|r|c|}
\hline Kriteria & Weighted Sum \\
\hline MKPD & 3,936 \\
\hline MTB & 1,586 \\
\hline PK & 0,376 \\
\hline KPM & 0,376 \\
\hline PPPD & 0,572 \\
\hline KDPD & 0,303 \\
\hline
\end{tabular}

3. Langkah 3

Bagi hasil weighted sum dengan nilai bobot masing masing kriteria.

Contoh: KDPD = 0,290/0,044 = 6,591

Tabel 9. Hasil Pembagian Weighted Sum dengan Bobot Kriteria

\begin{tabular}{|l|l|l|l|}
\hline Kriteria & $\begin{array}{c}\text { Weighted } \\
\text { Sum }\end{array}$ & Bobot & Hasil \\
\hline MKPD & 3,936 & 0,511 & 7,707 \\
\hline MTB & 1,586 & 0,233 & 6,791 \\
\hline PK & 0,376 & 0,058 & 6,496 \\
\hline KPM & 0,376 & 0,058 & 6,496 \\
\hline PPPD & 0,572 & 0,091 & 6,272 \\
\hline KDPD & 0,303 & 0,049 & 6,171 \\
\hline
\end{tabular}

\section{Langkah 4}

Jumlahkan seluruh hasil bagi seperti pada tabel 10. Kemudian bagi dengan banyak nya kriteria, seperti disini 6 kriteria. Maka akan didapatkan Eigen Max.

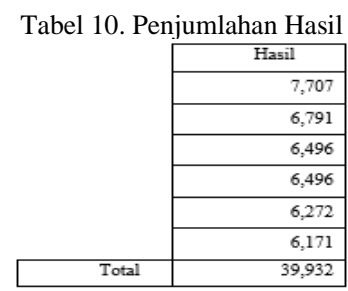

Maka, Eigen Max $=39,932 / 6=6,655$

5. Langkah 5

Setelah Eigen Max didapatkan, hitung Consistency Index.

$$
C I=\frac{6,655-6}{6-1}=0,131
$$

6. Langkah 6

Setelah Consistency Index didapatkan, hitung Consistency Ratio. Dengan banyak kriteria 6, maka $\mathrm{RI}=1,24$ (lihat tabel 1).

$$
C R=\frac{0,131}{1,24}=0,100
$$

Dari hasil perhitungan maka didapatlah nilai CR yaitu sebesar $\mathbf{0 , 1 0 0}$. Penilaian perbandingan dikatakan konsisten jika nilai CR tidak lebih besar dari 0,100 . Sehingga penilaian perbandingan kriteria penentuan guru terbaik di SDIT Amal Mulia tidak perlu dilakukan perhitungan ulang.

\subsection{Perhitungan dengan metode SAW.}

Berdasarkan perhitungan antar kriteria menggunakan metode Analytical Hierarchy Process (AHP), pada tabel 11 merupakan hasil perhitungan bobot kriteria yang telah konsisten dan ditetapkan. Total bobot, jika dijumlahkan tidak boleh lebih dari $100 \%$.
Tabel 11. Presentase Bobot Kriteria

\begin{tabular}{|c|c|c|c|}
\hline No. & $\begin{array}{c}\text { Kode } \\
\text { Kriteria }\end{array}$ & $\begin{array}{c}\text { Nama } \\
\text { Kriteria }\end{array}$ & Bobot \\
\hline 1. & GP1 & MKPD & $51 \%$ \\
\hline 2. & GP2 & MTB & $23 \%$ \\
\hline 3. & GP3 & PK & $6 \%$ \\
\hline 4. & GP4 & KPM & $6 \%$ \\
\hline 5. & GP5 & PPPD & $9 \%$ \\
\hline 6. & GP6 & KDPD & $5 \%$ \\
\hline \multicolumn{3}{|r|}{ Total } & $\mathbf{1 0 0} \%$ \\
\hline
\end{tabular}

Sebelum mendapatkan tabel normalisasi, harus diketahui nilai masing-masing alternatif yang didapat dari perjumlahan nilai kriteria yang disajikan pada

\begin{tabular}{|c|c|c|c|c|c|c|c|}
\hline \multirow{2}{*}{ No } & \multirow{2}{*}{ Alternatif } & \multirow{2}{*}{\multicolumn{6}{|c|}{ Kriteria }} \\
\hline & & GP1 & & & & GP5 & GP6 \\
\hline 1 & $\begin{array}{c}\text { Nabila } \\
\text { Khoirunnis }\end{array}$ & 60 & 60 & 40 & 60 & 60 & 60 \\
\hline 2 & Siti Rahma & 20 & 20 & 20 & 20 & 20 & 20 \\
\hline 3 & $\begin{array}{l}\text { Itasia } \\
\text { Nuryanti }\end{array}$ & 40 & 40 & 40 & 40 & 40 & 40 \\
\hline 4 & Agung & 80 & 80 & 80 & so & 80 & 80 \\
\hline 5 & $\begin{array}{c}\text { Hanifah } \\
\text { Pratiwi }\end{array}$ & 100 & 100 & 80 & 100 & so & 100 \\
\hline 6 & $\begin{array}{l}\text { Pratiwi } \\
\text { Budiono }\end{array}$ & 100 & 100 & 80 & 60 & 80 & 100 \\
\hline 7 & $\begin{array}{l}\text { Kholid } \\
\text { Sahputra }\end{array}$ & 100 & 100 & so & 80 & 20 & 100 \\
\hline 8 & Gema & 100 & 100 & 100 & 60 & 100 & 20 \\
\hline 9 & $\begin{array}{l}\text { Pamungkas } \\
\text { Tri Hastuti }\end{array}$ & 60 & 60 & 60 & 100 & 60 & 20 \\
\hline 10 & Ida Farida & 20 & 20 & 20 & 100 & 20 & 60 \\
\hline
\end{tabular}
Tabel 12.

Pertama dilakukan normalisasi menjadi tabel untuk menghitung nilai masing-masing kriteria, menghitung berdasarkan kriteria benefit atau kriteria cost menggunakan persamaan sebagai berikut:

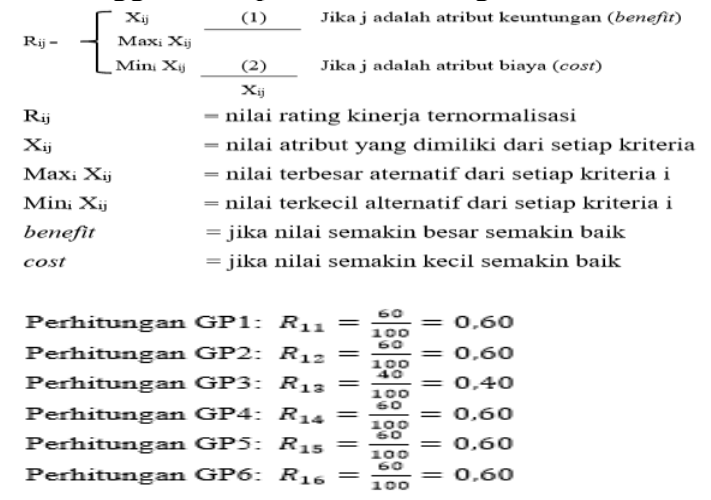

\begin{tabular}{|c|c|c|c|c|c|c|c|}
\hline \multirow{2}{*}{ No } & \multirow{2}{*}{ Alternatif } & \multicolumn{6}{|c|}{ Kriteria } \\
\hline & & GP1 & GP2 2 & GP3 & GP4 & GP5 & GP6 \\
\hline 1 & $\begin{array}{l}\text { Nabila } \\
\text { Ph }\end{array}$ & 0.60 & 0.60 & 0.40 & 0.60 & 0.60 & 0.60 \\
\hline 2 & Siti Rahma & 0,20 & 0,20 & 0,20 & 0,20 & 0,20 & 0,20 \\
\hline 3 & $\begin{array}{c}\text { Itasia } \\
\text { Nuryanti }\end{array}$ & 0,40 & 0,40 & 0,40 & 0,40 & 0,40 & 0,40 \\
\hline 4 & $\begin{array}{l}\text { Agung } \\
\text { Mulyadi }\end{array}$ & 0.80 & 0.80 & 0.80 & 0.80 & 0.80 & 0.80 \\
\hline 5 & $\begin{array}{l}\text { Hanifah } \\
\text { Pratiwi }\end{array}$ & 1 & 1 & 0,80 & 1 & 0,80 & 1 \\
\hline 6 & Budiono & 1 & 1 & 0,80 & 0,60 & 0,80 & 1 \\
\hline 7 & $\begin{array}{l}\text { Kholid } \\
\text { Sahputra }\end{array}$ & 1 & 1 & 0.80 & 0.80 & 0.20 & 1 \\
\hline 8 & $\begin{array}{c}\text { Gema } \\
\text { Pammungkas }\end{array}$ & 1 & 1 & 1 & 0,60 & 1 & 0,20 \\
\hline 9 & Tri Hastuti & 0,60 & 0,60 & 0,60 & 1 & 0,60 & 0,20 \\
\hline 10 & Ida $\mathrm{F}$ & 0,20 & 0,20 & 0,20 & 1 & & \\
\hline
\end{tabular}

Tabel 13. Hasil Normalisasi

1. Hasil Nilai Alternatif

Selanjutnya tabel normalisasi yang telah mendapatkan nilai per kriteria sebelumnya dihitung untuk mendapatkan alternatif yang terbaik. Berikut akan ditampilkan perhitungan untuk 1 alternatif aja. Alternatif lain mengikuti langkahnya.

Nabila Khoirunnisa

$$
\begin{aligned}
=\{(0,60 * 0,511)+ & (0,60 * 0,233)+(0,40 * 0,058) \\
& +(0,60 * 0,058)+(0,60 * 0,091) \\
& +(0,60 * 0,049)\}=0,588
\end{aligned}
$$

Hasil dari perhitungan akhir nilai alternatif dapat dilihat pada tabel 14 . 
Tabel 14. Hasil Nilai Alternatif

\begin{tabular}{|c|c|c|}
\hline No & Alternatif & Hasil \\
\hline 1 & Nabila Khoirumnisa & 0,588 \\
\hline 2 & Siti Rahma & 0,200 \\
\hline 3 & Itasia Nuryanti & 0,400 \\
\hline 4 & Agung Mulyadi & 0,800 \\
\hline 5 & Hanifah Pratiwi & $\mathbf{0 , 9 7 0}$ \\
\hline 6 & Budiono & 0,947 \\
\hline 7 & Kholid Sahputra & 0,904 \\
\hline 8 & Gema Pamumgkas & 0,938 \\
\hline 9 & Tri Hastuti & 0,604 \\
\hline 10 & Ida Farida & 0,266 \\
\hline
\end{tabular}

Dari perhitungan diatas, dapat disimpulkan bahwa alternatif yang terpilih sebagai guru terbaik adalah Hanifah Pratiwi dengan perolehan nilai akhir 0,970.

\subsection{Use Case Diagram}

Use Case Diagram merupakan gambaran interaksi pengguna sistem terhadap sistem dengan menjalankan fungsi-fungsi yang dapat diterima sistem tersebut. Use case diagram master, terdiri dari entry data user, entry data guru, entry data kriteria, entry data periode dapat dilihat pada gambar 6 . Use case diagram analisa, terdiri dari penilaian kriteria, bobot kriteria, analisa SAW dapat dilihat pada gambar 7. Use case diagram laporan terdiri dari hasil keputusan, penilaian kinerja, perangkingan guru, surat keputusan dapat dilihat pada gambar 8 .
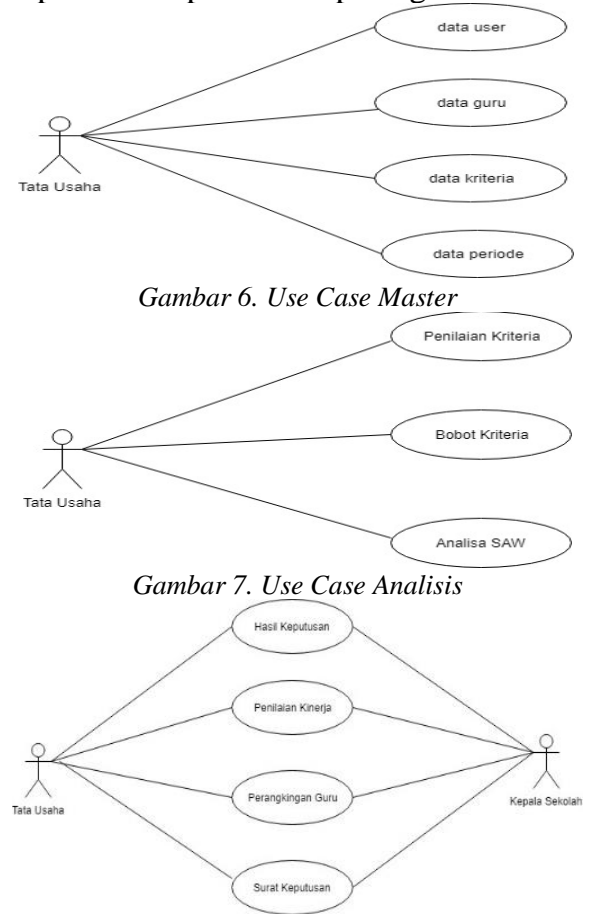

Gambar 8. Use Case Laporan

\subsection{Model Data}

Model ERD ini dirancang untuk pengembangan Sistem Pendukung Keputusan Pemilihan Guru Terbaik pada SDIT Amal Mulia. Model basis data ini menggunakan Entity Relationship Diagram, yang terdiri dari entitas Kriteria, Periode, Guru dan Hasil yang disajikan pada gambar 9 .

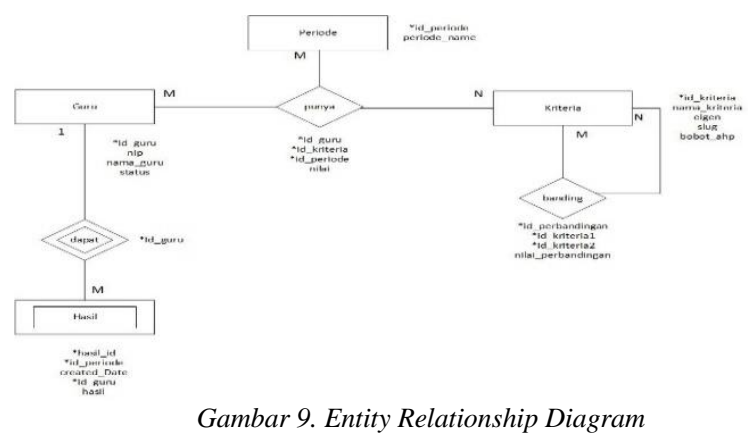

Berikut ini adalah Logical Record Structure dari rancangan basis data yang telah dibuat dan disajikan pada gambar 10 .

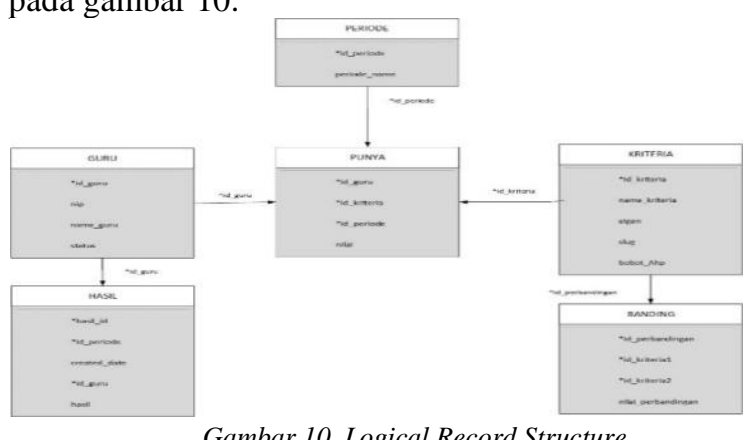

\subsection{Rancangan Layar}

1. Rancangan Layar Penilaian Kriteria

Halaman web pada gambar 11 ini digunakan untuk menampilkan menu data penilaian kriteria guru, dimana user akan mengentri nilai masingmasing guru berdasarkan kriteria yang telah ditetapkan.

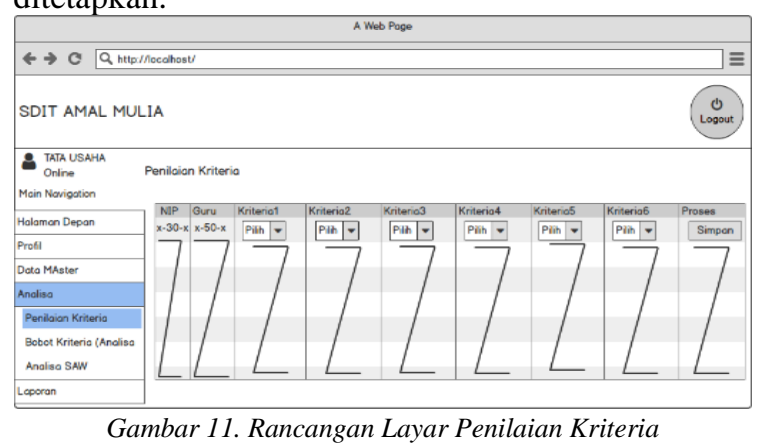

2. Rancangan Layar Tabel SAW

Halaman web pada gambar 12 ini digunakan untuk menampilkan menu tabel SAW.

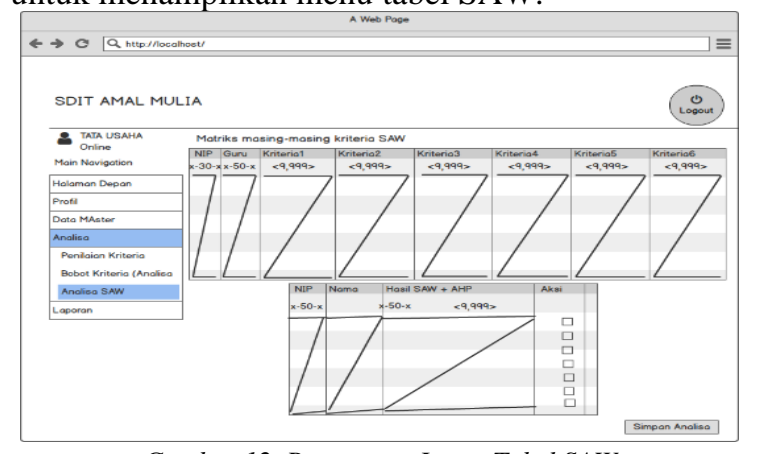

Gambar 12. Rancangan Layar Tabel SAW 
3. Rancangan Hasil Keputusan

Halaman web pada gambar 13 ini digunakan untuk menampilkan menu hasil keputusan.

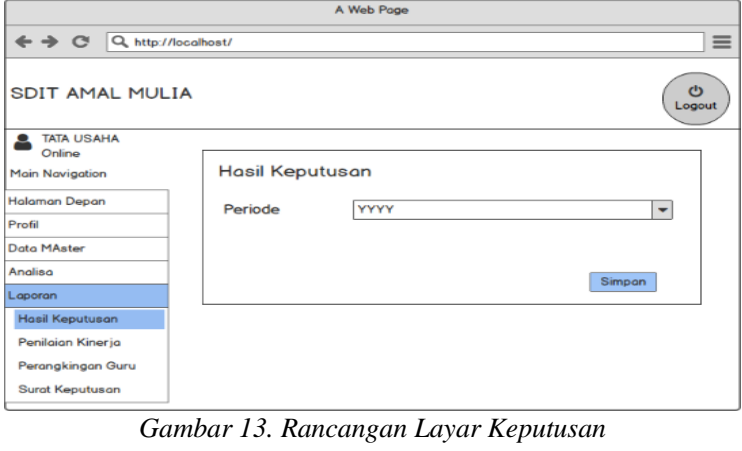

\section{KESIMPULAN}

Berdasarkan hasil implementasi yang telah dilakukan, maka dapat disimpulkan hasil penelitian ini adalah adanya aplikasi SPK mempermudah dalam pengambilan keputusan guru terbaik dengan cepat dan lebih baik berdasarkan data yang diproses. Sistem Pendukung Keputusan (SPK) penilaian kinerja guru menggunakan metode AHP dan SAW telah berhasil dibangun untuk menghasilkan keputusan yang lebih objektif berupa daftar perankingan guru terbaik. Mudah menentukan nilai bobot kriteria, sehingga diketahui kriteria mana yang prioritas, dan dapat terlihat keunggulan masing- masing guru pada kriteria tertentu.

\section{DAFTAR PUSTAKA}

[1] Rahayu, T., Krisnanik, E., and Hananto B., "Metode Analytical Hierarchy Process Dalam Menentukan Pemilihan Desa Terbaik", Jurnal RESTI, vol.3, no.1, pp.94-99, 2019.

[2] Puspitasari, Wahyu D. and Ilmi, D. K., "Sistem Pendukung Keputusan Pemilihan Dosen Berprestasi Menggunakan Metode Analytical Hierarchy Process (AHP)", ANTIVIRUS Jurnal Ilmiah Teknik Informatka, vol. 10, no. 2, pp. 5668, 2016.

[3] Hutasoit, R. S., et al, "Sistem Pendukung Keputusan Pemilihan Guru Terbaik Pada Smk Maria Goretti Pematangsiantar Menggunakan Metode Simple Additive Weighting (SAW)", Jurasik, vol. 1, no. 1, pp.56-63, 2017.

[4] Fara, Atika and Murtiyasa, B., "Sistem Pendukung Keputusan Pemilihan Guru Berprestasi Di Kecamatan Kradenan Kabupaten Grobogan Menggunakan Metode Simple Additive Weighting", Thesis, Universitas Muhammadiyah Surakarta, 2017.
[5] Mahdiana, D. and Kusumawardhany, N., "Penerapan Metode Analytical Hierarchy Process dan Simple Additive Weighting untuk pemilihan Dosen Terbaik", Konferensi Nasional Sistem Informasi (KNSI), 2018, vol. 8, pp.8-9.

[6] Gunarti, R., Nugroho, E., and Sanjaya, G. Y., "Pengembangan Prototype Sistem Informasi Customer Relationship Management di STIKES Husada Borneo Banjarbaru", Jurnal Information System Public Health, vol. 1, no. 2, 2016.

[7] Nofriansyah, D., Konsep Data Mining VS Sistem Pendukung Keputusan. Yogyakarta: Deepublish, 2015.

[8] E. Turban, Decision Support And Expert Systems: Management Support Systems. Prentice Hall PTR, 1993.

[9] Saaty, T. L., Fundamentals of Decision Making and Priority Theory With The Analytic Hierarchy Process, 6th ed., vol. 6. Pittsburgh: RWS Publications, 2000.

[10] Saaty, T. L. and L. G. Vargas, Decision Making With The Analytic Network Process, vol. 282. Switzerland: Springer, 2006.

[11] Hidayati, Tri A. and Rusdah, R., "Sistem Penunjang Keputusan Pemilihan Karyawan Terbaik Menggunakan Metode Analytical Hierarchy Process (AHP) Dan Simple Additive Weighting (SAW) Pada PT. Primasolusi Informatika Nusantara", Jurnal. IDEALIS, vol. 1, pp. 444-452, 2018.

[12] Fishburn, P. C., "A Survey of Multiattribute/Multicriterion Evaluation Theories," in Multiple criteria problem solving, Switzerland: Springer, 1978, pp.181-224. 